\title{
Is Public Administration a Profession?
}

\author{
Michael Davis ${ }^{1}$ \\ ${ }^{1}$ Center for the Study of Ethics in the Professions, Illinois Institute of Technology, Chicago, USA \\ Correspondence: Michael Davis, Humanities Department, Illinois Institute of Technology, Chicago, Illinois \\ 60616, USA. Tel: 1-773-288-8348. E-mail: davism@iit.edu
}

Received: June 8, 2013 Accepted: June 28, 2013 Online Published: September 29, 2013

doi:10.5539/par.v2n2p26 URL: http://dx.doi.org/10.5539/par.v2n2p26

\begin{abstract}
Public administrators are often said not to constitute a profession for one or more of at least ten reasons, for example, that they are not independent consultants but employees (and therefore lack "professional autonomy"). Yet, many public administrators seem to believe they belong to a profession. This paper argues that they are probably right. Doubts about the professional status of public administration seem to rely on one or another sociological definition having little to recommend it outside sociology. With a better definition, public administration looks very much like a profession. The question remaining is whether public administrators want their occupation to be a profession - and who they want to include in that profession.
\end{abstract}

Keywords: profession, ethics, public administration, morality, codes of ethics

"What I propose is that we try to act as a profession without actually being one, and perhaps even without the hope or intention of becoming one in any strict sense."-Dwight Waldo (1968)

\section{Introduction}

Government employs members of many professions: accountants, architects, chemists, engineers, lawyers, nurses, physicians, and so on. Though some of these professionals (for example, the chair of the department of civil engineering at a state university) hold positions in which they administer public funds, oversee the exercise of public authority, and otherwise engage in activities that count as public administration in some sense, such administrators are not the focus here; nor are those individuals who, working for private agencies, provide government with policy research, planning, or management. The focus here is that class of experts, managers, officials, and the like who, whatever other profession they belong to, are a) government employees, b) properly describe themselves as "public administrators", and c) properly describe what they do as "public administration". My question is: do these public administrators constitute a profession? (Note 1)

Public administrators (in this limited sense) may be thought not to constitute a profession for one or more of the following ten reasons: 1) they lack "professional autonomy" (being employees rather than independent agents); 2) they do not serve clients (only government or the public); 3) they typically lack the high status or high income of lawyers, physicians, and other "true professionals" (though some have it); 4) they are not licensed, registered, or otherwise formally certified as "public administrators" (in the way architects, lawyers, physicians, and other "true professions" are); 5) public administration lacks a distinctive body of scientific theory (instead borrowing its theory from business administration, economics, or political science); 6) public administration has no required curriculum through which all (or even most) public administrators must pass (though there are optional schools of public administration); 7) public administration is not itself typically a career but the culmination of a career in another occupation, 8) public administrators cannot exclude non-public administrators (business executives, chemists, engineers, politicians, and so on) from serving as public administrators; 9) most public administrators are members of no organization of public administrators, such as the American Society of Public Administration (ASPA) or the International City/County Management Association (ICMA); and 10) many public administrators, perhaps a majority, are members of a profession other than public administration (accounting, architecture, engineering, law, or the like).

Most of these reasons appear, in one form or another, in, for example, Pugh's classic paper (Pugh, 1989). Just seeing them together-all uncontroversial facts-may seem enough to settle the question of public administration's status as a profession. Clearly, public administration is not a profession, not even a 
quasi-profession, proto-profession, or anything close; it is (like "business management" or "office supervisor") a function or job description, nothing more.

And yet, some of us, including many public administrators, feel that public administration is a profession-or, at least, much more like accounting, engineering, or lawyering, than like managing a factory, sorting mail at the Post Office, or serving in a legislature. The problem is to explain how that can be - and what, therefore, is the relation between public administration and the other professions in government. For example, should public administrators do, as Waldo provocatively suggested almost a half century ago, simply admit that public administrations is not a profession but nonetheless "try to act like a profession... without the hope or intention of becoming one in any strict sense"? (Waldo, 1968)

What I shall argue here is that the ten reasons just given for doubting the professional status of public administration tell us more about the definition of profession being used (Waldo's "strict sense") than about the professional status of public administration. Relying on the wrong definition of profession explains most doubts about the professional status of public administration. I will, however, raise some doubts of my own, ones empirical research might clear up. My conclusion is that there is no decisive reason to conclude that public administration is not a profession "in the strict sense".

In writing this paper, I enter a largely empty field. While public administrators have written much about "professional codes" and "public professions", they have had little to say about profession as such. Consider, for example, Terry Cooper's Handbook of Administrative Ethics, a standard work of over seven hundred pages. Its index has three entries under "Profession". One ("codes of ethics") concerns the codes of ethics adopted by "professional associations" (without explaining why the associations in question are "professional"). The second ("attributes") takes the reader to a page of references none of which seems relevant to defining profession (not even the one work of mine listed there). The third ("definition") leads to a page uncritically reporting one of a dictionary's overly broad definitions (without explaining why that one was picked) and then lists six characteristics identified as "associated with profession". The page moves on to its next subject without even explaining how the dictionary definition and the list of characteristics fit together (or how the list was assembled). (Cooper, 2001, 96) Public administration seems to have paid no attention to recent work in the theory of profession.

\section{2. "Profession" in What Sense?}

"Profession" plainly has several senses in English. It can be a mere synonym for "occupation". It is in this sense that we may, without irony, speak of someone being a "professional thief" or "professional beggar", provided the person in question makes a living by the activity. Public administration is certainly a profession in this sense, but just as certainly this is not "the strict sense" relevant here. When we talk about public administration as a profession, we are not interested in classing public administrators with those who make a living by theft or begging.

"Profession" can instead be limited to honest occupations: "Carpentry is a profession; stealing is not." This is another sense that does not seem relevant here. While public administrators seem agreed that public administration is an honest occupation, they also seem agreed that, if it is a profession, it is so in a sense that carpentry is not. Public administration is "a higher calling" than carpentry.

"Profession" can also identify a special kind of honest occupation, for example, "a learned art" (one requiring advanced education of a certain sort). "Law is a profession; carpentry is not." Newer than the other senses, this one seems closer to "the strict sense" Waldo intended-without justifying the conclusion Waldo drew. (Note 2) It is not quite the sense we are looking for.

There are at least two approaches to defining "profession" in the special-kind-of-honest-occupation sense Waldo seems to intend, approaches that give importantly different results. One, what we may call "the sociological", has its origin in the social sciences. The other is philosophical. We must decide which approach to use before we can say anything useful about whether public administration is a profession.

\section{Sociological Approach}

The sociological approach tends to be statistical - or at least to sound empirical. Its statement of what a profession is, a definition of sorts, does not claim to offer necessary or sufficient conditions for an occupation to be a profession but merely to state what is true of "most professions", "the most developed professions", "the most important professions", or the like. Sociologists abstract a definition from a list of professions. There is no canonical list of any consequence. (Note 3) Each sociologist studying professions draws up her own list. Law and medicine are always on the list; the clergy, often; and other occupations commonly acknowledged as 
professions, such as architecture, engineering, the military, nursing, social work, or teaching, sometimes. (Note 4) What explains the different lists? Why doesn't sociology speak with one voice?

We may distinguish three traditions in the sociology of professions: the economic, the political, and the anthropological. Though individual sociologists may mix their elements, distinguishing them as "ideal types" will help us to understand them better, even in their less ideal (that is, mixed) forms. Different traditions tend to draw up different lists of paradigm professions.

The economic tradition interprets professions as primarily a means of controlling market forces for the benefit of the professionals themselves, that is, as a form of guild, labor union, or monopoly. The economic tradition has two branches: Marxist and free market. Among recent sociologists in the Marxist tradition, the best is Larson (1977). Among sociologists in the free-market tradition, Abbott (1988) is a good example. For sociologists in the economic tradition, whether Marxist or free market, it is the would-be members of a profession who, by acting together under favorable conditions, create a monopoly. Successful professions have high income, workplace autonomy, control of who can join, and so on; less successful professions lack some or most of these powers (more or less). Morality, if thought relevant at all, is thought relevant merely as a means to monopoly, a way of making a "trademark" (the profession's name) more attractive to potential employers. In this tradition, public administration - in the United States at least - can at best be a failed profession. Not only has it never had anything like a monopoly over jobs in public administration, its employers (various governments) have as well always controlled who would administer public affairs. Those who argue that public administration should not be a profession because professions are self-interested guilds are relying on (something like) this economic definition. (Note 5)

For the political tradition, however, public administration is plainly a profession in any country with a formal civil service. Often associated with Max Weber, the political tradition interprets profession as primarily a legal condition, a matter of reasonably effective laws that set standards of advanced education, make promotion a matter of merit, and impose discipline upon practitioners through formal, governmental structures (such as a merit system or licensing board). "Professional ethics" - and, indeed, even ordinary moral standards - are, if distinguished at all, treated as just another form of regulation. To be a profession (in this sense) is to be an occupation bureaucratized in a certain way. For the political approach, it is society (the government) that creates professions out of occupations, and society (the public) that benefits (whoever else also benefits). The political approach substitutes society's visible hands for the invisible hand of economics. The members of the profession have little or no part in making their profession. According to this tradition, public administration became a profession in the United States when government set standards of education, experience, and skill for the hiring, promotion, and discharge of public administrators (say, by the Civil Service Act of 1883).

The third tradition, the anthropological, is often associated with Emile Durkheim. It interprets professions as primarily cultural facts, the natural expression of a certain social function under certain conditions. Neither the members of the profession nor society can have much control over whether a certain occupation is a profession. Professions are a function of special knowledge used in a certain way, a community created by a common occupation requiring advanced study of some science. Among recent sociologists, the best of those working in the anthropological tradition is Eliot Freidson (for example, Freidson, 2001). Given this understanding of profession, it is easy to see why some public administrators might doubt that their occupation is a profession. There is little, if any, advanced scientific knowledge they share with all, or even most, other public administrators (though the curricula of schools of public administration overlap quite a bit). What public administrators seem to share, if they share anything, is (it is said) practical knowledge, skill, and judgment of a certain sort-and, in this respect, they resemble practitioners of a craft rather than a profession (as the anthropological tradition understands profession). (Note 6)

The lack of advanced scientific knowledge is, however, not decisive. While the lack of such knowledge certainly distinguishes public administration from science-based professions like engineering or medicine, it does not distinguish it from all professions. Some professions, such as law and journalism, also do without study of any particular science.

Distinguishing these three sociological traditions should make the point that the sociological approach has yet to yield a single definition of profession and, more importantly, is unlikely to. Sociology's way of working up a definition, that is, abstracting from a list of supposedly clear cases something common to most or all, is unlikely to yield a single definition - or, at least, is unlikely to until sociologists agree on a list sufficiently long to exclude most candidate definitions. Today, only two professions appear on all sociological lists (law and medicine). That is much too few to derive a definition at once specific enough to be useful and general enough to 
include most professions the professional status of which few doubt. Whatever the utility of a particular sociological definition for a particular research program, no such definition is likely to seem definitive to more than a minority of sociologists - and should, therefore, carry no weight at all with the rest of us. That being so, it is not surprising that, over the last few decades, philosophers have begun to develop their own definitions of profession, adding much that is new to our understanding of profession, most notably, insight into the connection between profession and morality.

\section{Philosophical Approaches}

Philosophical approaches typically seek necessary and sufficient conditions for an occupation to count as a profession. While the resulting definition may leave the status of a small number of would-be professions unsettled, it should at least explain (in a satisfying way) why the status of those would-be professions remains unsettled and what we would need to know (or what must change) to settle the question. Philosophical definitions are sensitive to counter-example in a way sociological definitions are not. Philosophers-and public administrators thinking like philosophers - cannot use the standard defense of sociologists confronted with a counter-example: "I said 'most', not 'all'." For a philosophical definition, even one clear counter-example is a significant problem.

We may distinguish two philosophical approaches to the definition of profession. One is (what we may call) the Cartesian. It answers the question, "What do $I$ think a profession is?" It attempts to piece together in a coherent way the contents of one person's mind. There may be as many Cartesian definitions of profession as there are people who ask themselves what they mean by "profession". The Cartesian approach has no procedure for mediating between one individual's definition and another's (assuming each accurately reports what the individual thinks). That, indeed, is one reason to reject the Cartesian approach. Another is that it can yield definitions as indifferent to morality as can the sociological approach. My favorite example of the Cartesian approach identifies the mafia as a profession. (Sanders, 1993) For another (more plausible) example of the Cartesian approach, see Koehn (1994).

The other philosophical approach is (what we may call) Socratic. It answers the question, "What do we - professionals and philosophers - really think a profession is?" A Socratic definition develops through a conversation or dialogue: Members of professions (or supposed professions) say what they mean by "profession", offering necessary and sufficient conditions. Philosophers, or members of one or another profession, test those definitions with counter-examples ("What about professors?"). They also consider the consequences of adopting the definition. Are the proposed defining conditions coherent? Are they informative? And so on. Any problem discovered through such questioning should be fixed by revising the definition appropriately. The definition is again examined. And so the process continues until everyone participating in the conversation is satisfied that no problem remains. It is this critical conversation that underwrites the claim that the resulting definition is "what we really think a profession is," that is, what we think it is upon enough calm, well-informed communal reflection. The conversation need not conclude with all those who started out believing themselves members of a profession ending up in a profession. Some participants, for example, "professional managers" or "professional athletes," may instead come to see that they are not members of a profession in any interesting sense - or, at least, in the sense they are in fact interested in. The conversation may begin again as soon as a new doubt arises. The Socratic approach does not end with a conclusion written in stone.

Unlike the sociological approach, the Socratic provides a procedure for resolving disputes. Individual insights must be incorporated into a single definition on which everyone taking part in the conversation agrees. The Socratic procedure concludes only when there is no live alternative to its preferred definition, a definition that necessarily excludes individual mistakes and even widespread but indefensible prejudice. In this respect, a Socratic definition is a product of reason rather than individual idiosyncrasy or social psychology.

\section{A Socratic Definition}

The following is, I think, the best definition that the Socratic approach has so far produced:

\section{A profession is a number of individuals in the same occupation voluntarily organized to earn a living by openly serving a moral ideal in a morally-permissible way beyond what law, market, morality, and public opinion would otherwise require.}

I shall not defend this definition here, since I have done that elsewhere. (Davis, 2002; Davis, 2009.) Here I shall merely explain it in enough detail to make clear its import, especially how it differs from sociological definitions discussed earlier. 
According to this Socratic definition, a profession is a group undertaking. This is one respect in which members of a profession differ from mere experts, officials, or managers. Experts, officials, and managers can be one of a kind but members of a profession cannot be. There can no more be a one-member profession than a one-member army or one-member family.

According to this Socratic definition, the would-be profession must consist of members of one occupation, that is, any typically full-time activity defined in part by a "discipline" (an easily recognizable body of knowledge, skill, and judgment) by which one can, and people typically do, earn a living. So, for example, law and medicine cannot form a single occupation - and so, a single profession-because their respective disciplines are too different. On the other hand, military medicine and civilian medicine can form a single occupation because the underlying discipline is much the same (as evidenced, for example, by the common requirement that medical officers hold a civilian medical license to practice medicine in the military).

This part of the Socratic definition has an important consequence for public administration. If "public administration" is interpreted too broadly — say, as the function of management in government-it will lack a single discipline and so must fail to be a profession (or, at least, a single profession). It may, therefore, be a mistake to include, for example, military officers among "public administrators" (as Mosher, 1982, 120-133, seems to). Not only the education of military officers but the ways they work may be too different from those of most public administrators. Perhaps the same is true even of some civilian managers, such as chief judges or university professors.

\section{Profession and Morality}

According to the Socratic definition, the occupation in question (the would-be profession) must organize to work in a morally permissible way. Where there is no morally permissible way to carry on the occupation, there can be no profession. There can, for example, be no profession of assassins (since murder is, all else equal, morally impermissible). While some professions are therefore conceptually impossible, public administration certainly does not seem to be one of them. Little of what public administrators typically do is even morally suspect.

The moral permissibility of a profession's occupation is one way that, according to this Socratic definition, profession is conceptually connected with morality. There are at least two others. One concerns "moral ideals". A moral ideal is a state of affairs all rational persons at their rational best recognize as a significant good, that is, as what (at their rational best) they want realized even if doing so would mean having to help in at least minor ways. A moral ideal thus differs in an important way from what Pugh called "a social ideal". (Pugh, 1989, 1.) A social ideal is what a society happens to count as ideal; a moral ideal is something society should count as an ideal (of a certain sort) whether it does or not (what at its rational best any society will count as an ideal).

For most professions, stating the distinctive moral ideal (in a rough way) is easy: accountants have organized to present financial information in ways both useful and accurate; architects, to build human habitations that are functional, safe, and beautiful; and so on. Accurate and useful financial information, functional, safe, and beautiful habitations for humans, and the like are goods we all recognize as significant, significant enough to justify a small contribution, for example, the increased burden of taxation needed to exempt from certain taxes the institutions that train the profession's practitioners.

Perhaps an individual can be morally decent without actively serving any moral ideal, but (according to the Socratic definition) an occupation cannot be a profession unless it serves one. What moral ideal might public administration serve? Public administration's ideal seems to be relatively clear, for example, from various codes of ethics: governmental management that is efficient, effective, fair, honest, lawful, and democratic. (ASPA Code of Ethics, 2013)

A profession serves its chosen moral ideal by setting and generally following appropriate standards for carrying on the occupation - standards that, going beyond what law, market, morality, and public opinion would otherwise require, are "special", that is, standards applying only to some. Without at least one special standard, an occupation (the would-be profession) would remain nothing more than an honest way to earn a living (whatever its ideal). So, for example, what distinguishes the professional soldier from the mere mercenary (however expert and honest) are the special standards of a professional soldier. To be a (good) mercenary, one need only competently carry out the terms of one's morally permissible contract of employment, but to be a (good) professional soldier, one must do more, for example, serve one's country honorably even when the contract of employment, ordinary morality, law, and public opinion do not require it.

A third way professions are connected with morality is merely implicit in the Socratic definition: the special standards of a profession are morally binding on every member of the profession simply because of that 
membership. These binding standards are what constitute the profession's necessary organization, not its learned societies or regulatory agencies. But how is it possible for standards that are morally permissible but not otherwise part of ordinary morality to be morally binding on members of a profession? That is an important question in the philosophy of professions. Here is my answer.

Professions must be "professed," that is, declared or claimed. Accountants must declare themselves to be accountants; architects must claim to be architects; and so on. Professionals must declare their profession in order to earn a living by it. They cannot be employed as such-and-such — say, a public administrator-unless potential employers know that they are "public administrators" in the special-standards sense. They cannot, that is, be employed as public administrators if they only claim (truthfully) to know a lot about public administration, to have earned a living by managing government affairs for several years, and to be good at it. If their profession has a good reputation for what it does, their declaration of membership will aid them in earning a living by it. They will find appropriate employment. If, however, their profession has a bad reputation (or an indifferent one), their declaration of membership will be a disadvantage (or, at best, pointless). Compare, for example, our response to the declaration "I am a chemist" with our response to "I am an alchemist".

Most analyses of profession try to find something that is "professed". Generally, it is merely technical knowledge, skill, or judgment. According to our Socratic definition, however, what is professed is always something more than merely technical; it includes a morally-binding commitment to a moral ideal and to the special standards implementing it. This brings "profession" much closer to one of its earliest senses-publicly taking vows as part of entering a religious order. The Socratic definition also makes the notion of a "value-free profession" incoherent. A profession can only choose to be neutral between certain values, for example, between those espoused by the party in power and the opposition (as long as the values in question fall within the bounds of ordinary morality). No profession can be neutral with respect to its own values (morality, its moral ideal, and its special standards).

Where members of a profession freely declare their membership, the profession's way of pursuing its moral ideal will be a voluntary, morally-permissible cooperative practice (not so different from an ordinary football game). The members of the profession will be members because they are entitled to be (by training, experience, certification, or the like), wished to be, spoke up accordingly, and were accepted as such. They may cease to be members simply by ceasing to claim membership.

In general, members of an occupation free to declare membership in the corresponding profession will declare it only if the declaration seems likely to benefit them, that is, to serve at least one purpose of their own at what seems a reasonable cost (whether the purpose is self-interested, altruistic, or idealistic). If employed (in part) because they declared membership, members of a profession will be in position to have the benefits of the profession (employment of certain kinds). They will also be in position to take advantage of the practice by doing less than the standards of practice require, even though the expectation was that they would do what the standards require (because they declared the appropriate profession). If cheating consists in violating the rules of a voluntary, morally permissible cooperative practice, then every member of a profession is in a position to cheat (just as every player in a football game is). Since, all else equal, cheating is morally wrong, every member of a profession has a moral obligation, all else equal, to do as the special standards of the profession require. The professional standards are morally binding in much the way playing by the rules is for anyone voluntarily playing football.

"Professionalism" is, strictly speaking, simply acting as the standards of the relevant profession require. To be a "professional" (or "true professional") is to be a member in good standing of the profession in question-or, by analogy, to act as if one were. A "professional association" is a formal organization which, consisting only of members of the profession in question, seeks to serve the profession's moral ideal.

Professional standards may, and generally do, vary from profession to profession. So, for example, the professional standards of lawyers differ from those of engineers. A profession's standards generally appear in a range of documents, including educational requirements, rules of practice, and disciplinary procedures. A profession is successfully organized insofar as its special standards are realized in the practice of its members, in what they do and how they evaluate one another. "Enforcement" is not a part of the definition of professional standards, only at most a practical auxiliary.

One of the documents stating professional standards may be a "code of ethics". Yet, while many definitions of profession require such a code as a condition of being a profession, the Socratic definition offered here does not. That omission is both deliberate and important. While a formal code of ethics is a central feature of professions in Australia, Canada, the United States, and most other English-speaking countries and has been since early in 
the twentieth century, few such codes seem to have existed outside English-speaking countries until after the Second World War. Yet professions seem to have long existed in at least some of those non-English-speaking countries so that, for example, American engineers could recognize a Dutch, French, or Spanish engineer of the 1920s as sharing their profession. In a profession without a formal code of ethics, the discipline (its "technical standards") must do the work of the code (though less explicitly and perhaps less effectively). Public administration could, then, be a profession even if it lacked a formal code of ethics.

\section{Morality, Ethics, and Law}

I have so far spoken of "ethics" without defining that term. That is risky. The term has at least as many senses as "profession". What I have just said about codes of ethics and technical standards will not make much sense to someone who does not understand "ethics" in something like the sense intended. So, I should now say what sense I intend.

By "ethics" I mean those morally-permissible standards of conduct governing members of a group simply because they are members of that group. In this sense, business ethics, is for people in business and no one else; professional ethics, for members of the relevant profession and no one else; and so on. Ethics - in this sense-is relative even though morality (a universal standard of conduct) is not. (Note 7) This sense makes clear why one profession's ethics may - and, indeed, should — differ from those of other professions - where "should" implies both expectation and propriety.

Ethics in this sense is not mere mores, custom, or practice. Ethics must at least be morally permissible. There can be no assassin's ethics or mafia ethics, except with ironic quotes around "ethics".

Though law is also relative, changing from jurisdiction to jurisdiction, ethics is not law for at least two reasons. First, not all laws are morally permissible, while ethical standards must, by definition, be at least morally permissible. Second, law applies to people whether they want it or not. That is why external means of enforcement (police, courts, penalties, and so on) are so central to the way we think about law. Ethics - or, at least, professional ethics as explained here-applies to people only because they voluntarily put themselves under it (by justifiably declaring themselves members of the profession in question and being accepted as such). Morality, an internal mode of enforcement, can therefore be-and, I think, is - the primary means of making professional ethics effective, just as it is what explains (in part at least) why promises are so often kept and football so often played fairly even when there is no referee. (For arguments favoring this extensive understanding of "enforcement", see Reiff, 2005.)

Law and professional ethics are distinct in another way. An occupation's status as a profession is more or less independent of license, state-imposed monopoly, and other special legal intervention. Computer scientists, journalists, professors, and the like can form professions even though none is in fact licensed, registered, or certified. Even a law that calls itself "a code of ethics" is a code of ethics only insofar as those it governs treat it not as an external imposition but as a statement of standards they all want everyone else in the group to follow even if that would mean having to do the same.

\section{Applying the Socratic Definition to Public Administration}

Having explained the Socratic definition of "profession" enough to make its chief features clear, I think its superiority to the sociological definitions is also clear. The Socratic definition explains the professional status of a large number of occupations one or another sociological definition denies: accounting, chemistry, engineering, journalism, and so on. So, we can now return to the ten reasons offered to show that public administration is not a profession. What status does the Socratic definition accord those reasons?

Nothing in the Socratic definition requires public administrators to be independent consultants, to have complete autonomy, or to be independent of external regulators. Public administrators need only have autonomy of a sort, that is, the right (and ability) to act as their professional standards require. That, however, is as possible in government as it is when an accountant, engineer, or lawyer serves the typical individual client. (For a sustained defense of this claim, see Davis, 1996.)

Nothing in the Socratic definition requires a profession to have clients, only to serve a moral ideal in morally permissible ways beyond what law, market, morality, and public opinion would otherwise require. Nor does that definition require that membership in a profession guarantee high social status or high income. All that membership in any profession need guarantee is that those who satisfy its standards (who conduct themselves as they "profess") will be "true professionals" and deserve the corresponding respect. Unfortunately, whether members of a profession get the respect they deserve is a contingency over which they have little or no control. 
Like other professionals, public administrators can only do as they should and hope enough people will notice and respond accordingly.

The Socratic definition requires that someone qualified to be a member of a profession declares to employers her membership in the profession and is accepted as such (or in some other way, benefits from that membership). Here public administration seems to have a problem. For most professions at least, a check of job advertisements reveals employers asking for the profession by name: "engineer", "lawyer", and so on. That does not seem to be true of "public administrator". There are, of course, listings for "public health administrator", "public school administrator", and the like, but in each case, "public" seems to modify the word next to it, not "administrator". If potential employers do not care to hire public administrators, then (according to the Socratic definition) public administrators constitute no more than a candidate profession that has yet to develop an appealing "trademark".

If ads in public administration were unique in this respect, we might have good reason to reject public administration's professional status. However, public administration is not unique in this respect. Several other professions, for example, journalism, share this absence from (most) job descriptions. So, for example, a web search for jobs in "journalism" reveals that most descriptions under that heading are "online sports copy editor", "production editor", "energetic reporter", and so on. Only rarely will an advertisement mention "journalist" (for example, "corporate journalist"). (Note 8) I do not consider this an impediment to journalism being a profession because employers seem to treat these subcategories as simply more exact descriptions of what they want. Since a copy editor is a kind of journalist (which is why the ad appears in response to a search for jobs in "journalism"), when potential employers ask for a "copy editor", they are in effect asking for a journalist with such-and-such additional skills, not for something other than a journalist. When a journalist identifies herself as a "copy editor", she is implicitly declaring membership in the profession of journalism. Certainly, in my experience, if you ask a copy editor working for a newspaper or other news media whether she is a journalist, she will generally answer yes. Perhaps much the same is true of public administration. That is an empirical question-one needing to be investigated before we can be sure that public administration is a profession. Does "public administrator" function as a "trademark"?

However that investigation turns out, nothing in the Socratic definition requires public administration to have a foundation in science or theoretical knowledge of any other sort, only a discipline associated with the underlying occupation (a discipline being certain settled ways of doing the work in question, not necessarily an academic subject). The discipline may be acquired in any number of ways, not necessarily through a formal curriculum. Nothing in the Socratic definition requires a college or graduate degree in public administration —or any other formal education. That most professions do require college or graduate education is a fact about the underlying occupations (what is required for competence), not about profession as such. Some professions, such as journalism, resemble public administration in having no specific educational requirement.

Nothing in the Socratic definition requires public administration to be a life-long career. Nor does the definition require public administrators to have a monopoly, that is, the right to exclude non-public-administrators from jobs public administrators typically hold. The only right to exclude that follows from the Socratic definition is the right to say of non-public-administrators that they are not public administrators — or, at least, that they are not proper public administrators but mere bureaucrats, governmental managers, or the like. Public administrators have a moral right to preserve their "trademark" (assuming they have one).

Nothing in the Socratic definition requires public administrators to be members of a "professional association," such as the ASPA. That is just as well. In the US, few professions, not even law or medicine, can now claim that a majority of the profession's members belong to any of its formal organizations. The only organization that public administrators must belong to if public administration is to be a profession is the profession of public administration itself, a membership which comes with openly practicing public administration as its professional standards require.

What about what we might call "the problem of dual professions"? We have already noted that some professions, such as the military or judicial, seem too different from public administration for its members to share an occupation with public administrators (strictly so called). Might that be true of all professions, from accountant to zoologist? The answer, I think, is generally no. Most professions seem (as a matter of fact) to have standards of practice consistent enough with those of public administration. So, for an accountant, lawyer, physician, or zoologist who has taken a management role in government, nothing in that first profession seems to stand systematically in the way of acting as public administrators should. That, however, is another empirical claim, one that further investigation might refute. 
But before beginning that investigation, we should consider another institution in which dual professions are common, the university. Thinking about dual professions in the university should help investigators better appreciate what to look for when they try to determine whether one can practice public administration properly while remaining a member in good standing of another profession (whether accounting, architecture, engineering, law, or the like).

\section{Dual Professions}

Public administrators with another profession resemble professors who teach in professional programs. Professors of accounting are typically accountants; professors of architecture, architects; and so on. They are subject both to their respective professional standards and to the standards governing university professors. Sometimes that double profession produces an ethical problem neither profession would produce alone. For example, if a student says something in Criminal Procedure suggesting that he would not be a good lawyer (for example, that he would happily lie to a judge to help a client), the law professor will have a difficult choice. The student is entitled to academic freedom, including the right to speak his mind in class (on relevant topics when called upon). On the other hand, as a lawyer, the law professor has a duty to report to the appropriate Character and Fitness Committee any doubts she has about a candidate's fitness to practice law. Should she give the student the benefit of the doubt? If she were not also a lawyer, the answer would be clear. If she were not also a university professor, the answer would again be clear-but different.

There are, of course, at least two solutions to this problem of dual professions. One is to have faculty in professional schools who, though trained in the profession, are mere academics, scholars rather than members of the profession. Many professions have given up this way of avoiding the problem because they want professors who understand the practical side of what they teach. The other way to avoid the problem is to move the professional school out of the university, denying students academic freedom. A century and a half ago, most professional schools in the US were like that, free-standing. But as scholarship became increasingly important to teaching an up-to-date version of the discipline, these free-standing schools (normal schools, polytechnics, theological seminaries, medical colleges, and so on) either turned into universities or were absorbed into them. For teaching (most) professions, the problem of dual professions has been judged better than the solutions available.

Something like that may also be true of public administration. Much of governmental management consists in overseeing the work of a particular profession. Administrators in the Justice Department typically oversee the work of lawyers. Administrators in the Centers for Disease Control typically oversee the work of physicians, statisticians, or biologists. And so on. One way to deal with the variety of professions is to develop specialized administrators, for example, legal administrators for lawyer-dominated departments; medical administrators for medicine-dominated departments; and so on. Another way is to develop a generalized public administrator who can move from one department to another (as, in theory, MBAs are supposed to be able to move from one department of business to another). In the US at least, we seem to have rejected both these alternatives (for much of government). We seem to have rejected the specialized administrator because there seems to be a common core to public administration, despite the variety of civilian agencies in which public administrators work. For many agencies at least, we want to be able to move administrators from one to another. In much the same way, we seem to have rejected the generalized administrator, especially in the lower levels of administration, because it takes years to develop the specialized expertise needed to manage the work of experts well. We seem to have found that most public administrators are generally enough alike, whether they have another profession or not, to benefit from working together in a common profession. If that were not true, the ASPA should have few, if any, members; there should be no schools or programs of public administration, much less a body accrediting them (such as the National Association of Schools of Public Affairs and Administration); and public administration would rarely, if ever, wonder whether it is a profession.

\section{Conclusion}

The ten reasons with which this paper began do not, then, severally or even together, show that public administration is not a profession. Surprisingly, none is even relevant to whether public administration is a profession. To decide whether public administration is a profession, according to the Socratic definition (now "the strict sense"), we must determine whether public administrators (properly so called) belong to an occupation the members of which are voluntarily organized to earn a living by openly serving a moral ideal in a morally-permissible way beyond what law, market, morality, and public opinion would otherwise require.

For reasons given above, public administrators may — and probably do - belong to a distinct occupation, one concerned with properly carrying out government policy, an occupation distinguished by the discipline taught in 
(among other places) government offices and schools of public administration. Public administrators differ from other public servants (who also carry out government policy) in having significant authority over others. They are, in that respect, like other managers. They differ from other managers, however, in seeking to serve the public interest rather than some private interest. They are public administrators. The public interest is part of their moral ideal (though perhaps not the most interesting part). The exact content of that moral ideal is open to debate.

Of course, defining its moral ideal is not only a problem for public administration. After many years studying professions, I have come to expect defining the exact content of its moral ideal to be a problem in every profession. For example, lawyers seem regularly to debate whether their moral ideal, justice-under-law, includes substantive justice or just procedural justice. Lawyers also sometimes wonder whether they should bend the rules to help a client get what (according to natural justice) she deserves. Wondering openly about such things is, however, not evidence against an occupation being a profession. Wondering openly about them is part of constituting a profession, the continuing discussion that helps to make a number of practitioners into a profession ("in the strict sense").

\section{References}

Abbott, A. (1988). The System of Professions: An Essay into the Division of Expert Labor. Chicago: University of Chicago Press.

American Society of Public Administration, Code of Ethics. Retrieved June 6, 2013, from http://www.aspanet.org/public/ASPA/Resources/Code_of_Ethics/ASPA/Resources/Code\%20of\%20Ethics1 .aspx?hkey=acd40318-a945-4ffc-ba7b-18e037b1a858

Cooper, T. L. (2001). (Ed.). Handbook of Administrative Ethics (2nd ed.) New York: Mercel Dekker, Inc.

Davis, M. (1996). Professional Autonomy: A Framework for Empirical Research. Business Ethics Quarterly, 6(Oct.), 441-460. http://dx.doi.org/10.2307/3857498

Davis, M. (2002). Profession, Code, and Ethics. Aldershot, England: Ashgate.

Davis, M. (2009). Is Engineering a Profession Everywhere? Philosophia, 37(June), 211-225. http://dx.doi.org/10.1007/s11406-008-9125-9

Freidson, E. (2001). Professionalism: The Third Logic. Chicago: University of Chicago Press.

Koehn, D. (1994). The Ground of Professional Ethics. London: Routledge.

Kultgen, J. (1988). Ethics and Professionalism. Philadelphia: University of Pennsylvania Press.

Larson, M. S. (1977). The Rise of Professionalism. Berkeley: University of California Press.

Mosher, F. C. (1982). Democracy and the Public Service (2nd. ed.). New York: Oxford University Press.

O'Toole, B. J. (2006). The Emergence of a 'New' Ethical Framework for Civil Servants. Public Money \& Management, 26(January), 39-45. http://dx.doi.org/10.1111/j.1467-9302.2005.00499.x

Pugh, D. L. (1989). Professionalism in Public Administration: Problems, Perspectives, and the Role of ASPA. Public Administration Review, 49(January-February), 1-8. http://dx.doi.org/10.2307/977223

Reiff, M. R. (2005). Punishment, Compensation, and Law: A Theory of Enforceability. Cambridge: Cambridge University Press. http://dx.doi.org/10.1017/CBO9780511499241

Sanders, J. T. (1993). Honor among Thieves: Some Reflections on Codes of Professional Ethics. Professional Ethics, 2(Fall/Winter), 83-103. http://dx.doi.org/10.5840/profethics199323/411

Sciulli, D. (2005). Continental Sociology of Professions Today: Conceptual Contributions. Current Sociology, 53(November), 915-942. http://dx.doi.org/10.1177/0011392105057155

Torstendahl, R. (2005). The Need for a Definition of 'Profession. Current Sociology, 53(November), 947-951. http://dx.doi.org/10.1177/0011392105058029

\section{Notes}

Note 1. In what follows, my focus is government service in the United States only because most of the relevant literature has that focus. For a rare exception, see O'Toole (2006), about public administration in the UK.

Note 2. Indeed, this is (essentially) the dictionary definition quoted in Cooper, 2001, 96. 
Note 3. So, for example, Pugh, 1989, 1 (cited in Cooper, 2001, 96) claims that "[at] least six overlapping traits deserve mention [as distinguishing professions from other occupations]: (1) a cast of mind (i.e., a self awareness); (2) a corpus of theory and knowledge; (3) a social ideal; (4) ethical standards; (5) formal organization to promote its interests; and (6) a 'hall of fame' to recognize outstanding leaders." While most of these appear in some other attempts to characterize profession, the last (a hall of fame) seems to be Pugh's own invention. Pugh gives no source for this list.

Note 4. For more on the enormous variety of sociological definitions, see Kultgen, 1988, especially, pp. 60-62; or the recent exchange between: Sciulli, 2005, and Torstendahl, 2005.

Note 5. See, for example, Pugh (1989), 4: "Willbern warned that the very nature of the public service in a constitutional democracy was incompatible with the characteristics of a profession and the self-interested behavior of professionals."

Note 6. See, for example, the "liberal definition" of profession in Mosher, 1982, 115-116: "1. a reasonably clear-cut occupational field, 2. which ordinarily requires higher education at least through the bachelor's level, and 3. which offers a lifetime career to its members." The "ordinarily" signals a sociological definition (or wiggle room for those public administrators who rise by passing departmental tests, not by higher education). The absence of any mention of markets or legal arrangements signals an anthropological definition. Though less detailed than Pugh's, Mosher's definition is nonetheless unnecessarily narrow. The requirement of "lifetime career" excludes any occupation (such as the military, firefighters, and police) in which physical requirements might make early retirement (and a second career) necessary.

Note 7. For our purposes, morality consists of those standards of conduct every moral agent should follow. Morality is a universal minimum, our standard of moral right and wrong.

Note 8. See, for example, http://www.journalismjobs.com/Search_Jobs_all.cfm (accessed October 29, 2012).

\section{Copyrights}

Copyright for this article is retained by the author(s), with first publication rights granted to the journal.

This is an open-access article distributed under the terms and conditions of the Creative Commons Attribution license (http://creativecommons.org/licenses/by/3.0/). 